\title{
Short-term and long-term epoprostenol (prostacyclin) therapy in pulmonary hypertension secondary to connective tissue diseases: results of a pilot study
}

\author{
M. Humbert, O. Sanchez, M. Fartoukh, J.-L. Jagot, C. Le Gall, O. Sitbon, F. Parent, G. Simonneau
}

Short-term and long-term epoprostenol (prostacyclin) therapy in pulmonary hypertension secondary to connective tissue diseases: results of a pilot study. M. Humbert, O. Sanchez, M. Fartoukh, J.-L. Jagot, C. Le Gall, O. Sitbon, F. Parent, G. Simonneau. (C)RS Journals Ltd 1999.

ABSTRACT: Continuous intravenous epoprostenol improves exercise capacity, haemodynamics, and survival in severe primary pulmonary hypertension. Pulmonary hypertension can also be life-threatening in patients with connective tissue diseases.

In a prospective open monocentre uncontrolled study, the effects of epoprostenol were evaluated in patients with severe pulmonary hypertension secondary to connective tissue diseases who were unresponsive to oral vasodilators (including calcium channel blockers) and continued to be in the New York Heart Association (NYHA) functional class III or IV despite conventional medical therapy. Seventeen patients received epoprostenol administered by a portable infusion pump associated with conventional therapy (oral anticoagulants, diuretics, supplemental oxygen).

During the first six weeks of therapy, two $(12 \%)$ patients died, of pulmonary oedema $(n=1)$ and severe sepsis $(n=1)$. In the fifteen remaining subjects, clinical and haemodynamic parameters improved significantly at six weeks. These patients were subsequently monitored for $80 \pm 48$ (range 14-154) weeks after initiation of epoprostenol. Five $(33 \%)$ patients died, of right heart failure $(n=2)$, severe sepsis $(n=2)$ or syncope $(n=1)$ and two patients were successfully transplanted 24 and 52 weeks after initiation of epoprostenol. Seven of the remaining eight patients had a persistent clinical improvement.

Short-term epoprostenol therapy is effective in some patients with connective tissue diseases as demonstrated by better clinical status and haemodynamics at six weeks. However, this study reports several cases of early and late major complications including severe sepsis and pulmonary oedema. Additional information is needed to evaluate the benefit: risk ratio of long-term epoprostenol therapy in pulmonary hypertension secondary to connective tissue diseases.

Eur Respir J 1999; 13: 1351-1356.
Service de Pneumologie et Réanimation Respiratoire, UPRES EA2705, Hôpital Antoine Béclère, Clamart, France.

Correspondence: M. Humbert

Service de Pneumologie et Réanimation Respiratoire

UPRES EA2705

Hôpital Antoine Béclère

157 rue de la Porte de Trivaux

92140 Clamart

France

Fax: 33146303824

Keywords: Connective tissue diseases epoprostenol

pulmonary hypertension

Received: May 51998

Accepted after revision November 151998

This study has been supported in part by a grant from Laboratoire GlaxoWellcome.
Epoprostenol (prostaglandin $\mathrm{I}_{2}$, prostacyclin) is a potent vasodilator and inhibitor of platelet aggregation produced by vascular endothelium [1]. Epoprostenol reduces pulmonary vascular resistance and increases cardiac output and oxygen delivery when administered acutely to some patients with primary pulmonary hypertension (PPH) [1]. Moreover, continuous intravenous epoprostenol produces substantial and sustained haemodynamic and symptomatic responses as well as improving survival in severe PPH refractory to conventional medical therapy [2-6].

Pulmonary hypertension is an uncommon but well recognized complication of connective tissue diseases (CTD) such as scleroderma, mixed connective tissue disease, and systemic lupus erythematosus [7-14]. In CTD the cause of vascular involvement is unknown, pathological changes are often those of pulmonary hypertensive arteriopathy similar to those observed in PPH, exercise capacity is greatly affected, and the prognosis of pulmonary hypertension is poor [7-15]. This study has therefore attempted to evaluate the effects of the continuous intravenous infusion of epoprostenol on exercise capacity, haemody- namics, and survival in patients with severe pulmonary hypertension secondary to CTD who were unresponsive to oral vasodilators (including calcium channel blockers) and continued to be in the New York Heart Association (NYHA) functional class III or IV despite conventional therapy, which consisted of the administration of oral anticoagulants, diuretics, and supplemental oxygen.

\section{Methods}

\section{Patient population}

From October 1993 to December 1997, seventeen patients referred to the authors' institution for severe pulmonary hypertension secondary to CTD entered this study. The clinical and demographic characteristics of these subjects are shown in table 1. The diagnosis of pulmonary hypertension was established by right heart catheterization. Secondary causes of pulmonary hypertension other than CTD were eliminated by perfusion lung scanning 
Table 1. - Clinical details of patients (baseline)

\begin{tabular}{|c|c|c|c|c|c|c|c|c|c|c|c|}
\hline $\begin{array}{l}\text { Patient } \\
\text { No. }\end{array}$ & $\begin{array}{l}\text { Age } \\
\text { yrs }\end{array}$ & Sex & $\begin{array}{c}\text { Collagen } \\
\text { vascular disease }\end{array}$ & $\begin{array}{c}\text { 6MWT } \\
\mathrm{m}\end{array}$ & $\begin{array}{l}\text { NYHA } \\
\text { functional class }\end{array}$ & $\begin{array}{l}\text { mRAP } \\
\text { mmHg }\end{array}$ & $\begin{array}{l}\text { mPAP } \\
\text { mmHg }\end{array}$ & $\begin{array}{c}\mathrm{mPCWP} \\
\mathrm{mmHg}\end{array}$ & $\stackrel{\mathrm{CI}}{\mathrm{L} \cdot \mathrm{min} \cdot \mathrm{m}^{-2}}$ & $\begin{array}{l}\text { PVR } \\
\mathrm{U} \cdot \mathrm{m}^{-2}\end{array}$ & $\begin{array}{l}\mathrm{Sv}_{\mathrm{v}} \mathrm{O}_{2} \\
\%\end{array}$ \\
\hline 1 & 29 & $\mathrm{~F}$ & MCTD & 350 & III & 6 & 51 & 6 & 2.07 & 24.5 & 64 \\
\hline 2 & 48 & $\mathrm{~F}$ & CREST & 320 & III & 4 & 49 & 5 & 2.28 & 21.3 & 71 \\
\hline 3 & 35 & F & SLE & 320 & III & 20 & 53 & 4 & 1.27 & 42.0 & 35 \\
\hline 4 & 65 & $\mathrm{~F}$ & CREST & 145 & IV & 15 & 55 & 10 & 2.32 & 23.9 & 27 \\
\hline 5 & 62 & M & CREST & 350 & III & 5 & 50 & 6 & 2.52 & 20.0 & 64 \\
\hline 6 & 54 & $\mathrm{~F}$ & CREST & 125 & IV & 20 & 59 & 10 & 1.79 & 33.1 & 51 \\
\hline 7 & 45 & $\mathrm{~F}$ & SS & 295 & IV & 20 & 53 & 12 & 2.05 & 25.7 & 38 \\
\hline 8 & 41 & $\mathrm{~F}$ & PGS & 450 & III & 14 & 49 & 5 & 2.01 & 24.2 & 58 \\
\hline 9 & 49 & $\mathrm{~F}$ & SLE & 240 & III & 9 & 43 & 7 & 2.69 & 16.0 & 55 \\
\hline 10 & 60 & $\mathrm{~F}$ & MCTD & 395 & III & 16 & 58 & 12 & 2.17 & 26.9 & 46 \\
\hline 11 & 43 & $\mathrm{~F}$ & SS & 0 & IV & 10 & 43 & 6 & 1.94 & 22.3 & 53 \\
\hline 12 & 63 & $\mathrm{~F}$ & CREST & 90 & IV & 10 & 49 & 10 & 2.75 & 17.8 & 66 \\
\hline 13 & 27 & $\mathrm{~F}$ & SLE & 350 & III & 16 & 73 & 10 & 2.54 & 38.9 & 46 \\
\hline 14 & 34 & F & SLE & 100 & IV & 3 & 42 & 4 & 1.60 & 26.3 & 27 \\
\hline 15 & 24 & $\mathrm{~F}$ & SLE & 0 & IV & 20 & 65 & 4 & 1.53 & 42.3 & 37 \\
\hline 16 & 34 & F & MCTD & 240 & IV & 19 & 40 & 10 & 2.04 & 19.6 & 49 \\
\hline 17 & 64 & $\mathrm{~F}$ & CREST & 185 & IV & 15 & 59 & 7 & 1.78 & 33.1 & 50 \\
\hline Mean & 46 & - & - & 233 & - & 13 & 52 & 8 & 2.08 & 26.3 & 49 \\
\hline$\pm \mathrm{SD}$ & 14 & - & - & 137 & - & 6 & 9 & 3 & 0.41 & 7.6 & 13 \\
\hline
\end{tabular}

F: female; M: male; CI: cardiac index; CREST: CREST syndrome; MCTD: mixed connective tissue disease; mPAP: mean pulmonary artery pressure; mPCWP: mean pulmonary capillary wedge pressure; mRAP: mean right atrial pressure; NYHA: New York Heart Association; PGS: primary Sjögren's syndrome; SLE: systemic lupus erythematosus; SS: systemic sclerosis; $S_{\mathrm{v}, \mathrm{O}_{2}}$ : mixed venous oxygen saturation; PVR: pulmonary vascular resistance; 6MWT: 6 minute walk test. $(1 \mathrm{mmHg}=0.133 \mathrm{kPa}$.)

and/or pulmonary angiography and echocardiography [16]. No patient had significant interstitial lung disease as demonstrated by pulmonary function tests (total lung capacity of at least $60 \%$ of predicted values) and highresolution computed tomography of the chest (either normal or showing mild interstitial disease). All patients developed severe pulmonary hypertension despite CTD management, including corticosteroids $(n=10)$, cyclophosphamide $(n=7)$, D-penicillamine $(n=5)$, hydroxychloroquine $(n=4)$, methotrexate $(n=2)$, azathioprine $(n=1)$, gold salts $(n=1)$, cyclosporine $(n=1)$, and colchicine $(n=3)$. Patients were in NYHA functional class III or IV despite optimal medical therapy, which consisted of the administration of oral anticoagulants, diuretics, and supplemental oxygen. All patients were referred to the authors' centre because they were unresponsive to the vasodilators commonly used to treat the disease. Some patients were treated with calcium channel blockers before referral to the centre. In this case, calcium channel blockers were stopped because they did not provide clinical or haemodynamic benefits, as demonstrated by the patients' clinical outcome.

\section{Right heart catheterization and exercise capacity}

Right heart catheterization was performed on all patients using standard techniques. Mean right atrial pressure, mean pulmonary artery pressure (mPAP), mean pulmonary capillary wedge pressure, cardiac index (CI), mixed venous oxygen saturation $\left(\mathrm{S}_{\mathrm{v}} \mathrm{O}_{2}\right)$, and pulmonary vascular resistance (PVR) were measured at baseline, and at six weeks after initiation of continuous intravenous epoprostenol in all patients.

Acute vasodilator challenge was performed after stopping all vasodilator therapy (with a wash-out period of at least five half-lives before right-heart catheterization). It has previously been demonstrated that inhaled nitric oxide at low dose is an effective, safe and reliable substitute for epoprostenol in screening for acute pulmonary vasodilator responsiveness during therapeutic assessment of patients with PPH [17]. Therefore, baseline vasodilator response was tested with a short-term inhalation of an air/nitric oxide (10 parts per million (ppm)) mixture administered through a face mask over a 10-min period, as previously described [17]. Acute vasodilator response was defined by a fall both in mPAP and PVR by $>20 \%$. Using these criteria, no patient responded to vasodilator. After initiation of epoprostenol therapy, scheduled visits included right heart catherization every 3-6 months. Exercise capacity was assessed in parallel with the use of the unencouraged 6-min walk test (6MWT). Patients who were unable to walk because of pulmonary hypertension were assigned a value of $0 \mathrm{~m}$.

\section{Treatment}

All patients received continuous infusion of epoprostenol (Flolan $($ ) ) at doses based on clinical signs and symptoms of pulmonary hypertension. They also received oral anticoagulants in doses adjusted to achieve an international normalized ratio (INR) of $\sim 2.0$. Adjustments in concomitant medications (diuretics, oxygen) were allowed during the study on the basis of clinical judgement. Venous access for the infusion of epoprostenol was obtained by the insertion of a permanent catheter into a subclavian vein. Epoprostenol was infused continuously with the use of a portable infusion pump (Graseby Medical Ltd., Watford, UK). Before being discharged from the hospital patients were trained in sterile technique, catheter care, and drug preparation and administration. Epoprostenol therapy was initiated at a dose ranging $8-16 \mathrm{ng} \cdot \mathrm{kg}^{-1} \cdot \mathrm{min}^{-1}(11 \pm 2 \mathrm{ng}$. $\left.\mathrm{kg}^{-1} \cdot \mathrm{min}^{-1}\right)$. All patients were evaluated six weeks after initiation of continuous intravenous epoprostenol and visits were scheduled every 3 months. 


\section{Statistical analysis}

Data were analysed with a Macintosh computer (Apple Company, New York, NY, USA) using the Statview ( 4.5 Software (Abacus Concepts Inc., Berkeley, CA, USA). Data are presented as mean \pm SD. The paired Student's t-test was used for clinical and haemodynamic comparison between baseline values and those obtained after inititiation of continuous intravenous epoprostenol.

\section{Results}

The baseline demographic, clinical, and haemodynamic characteristics of patients are shown in table 1. Epoprostenol therapy was initiated at a dose ranging $8-16 \mathrm{ng} \cdot \mathrm{kg}^{-1}$. $\mathrm{min}^{-1}\left(11 \pm 2 \mathrm{ng} \cdot \mathrm{kg}^{-1} \cdot \mathrm{min}^{-1}\right)$. All patients were evaluated at six weeks and 15 patients were subsequently monitored during $80 \pm 48$ weeks (range 14-154) with scheduled visits every three months. In these patients, epoprostenol therapy was progressively increased to doses ranging 10-26 $\mathrm{ng} \cdot \mathrm{kg}^{-1} \cdot \mathrm{min}^{-1}\left(17 \pm 5 \mathrm{ng} \cdot \mathrm{kg}^{-1} \cdot \mathrm{min}^{-1}\right)$ at 6 months, representing an average increase of $1.1 \mathrm{ng} \cdot \mathrm{kg}^{-1} \cdot \mathrm{min}^{-1}$ every month. At the last follow-up visit, doses were $12-28 \mathrm{ng} \cdot \mathrm{kg}^{-1}$. $\min ^{-1}\left(19 \pm 5 \mathrm{ng} \cdot \mathrm{kg}^{-1} \cdot \mathrm{min}^{-1}\right)$.

\section{Exercise capacity and NYHA functional class}

Results at six weeks. Fifteen patients were evaluated six weeks after initiation of continuous intravenous epoprostenol. Exercise capacity improved in $13(87 \%)$ patients. The mean change in 6MWT from baseline was an increase of $109 \mathrm{~m}(\mathrm{p}=0.01)$ (fig. 1). NYHA functional class improved in $11(73 \%)$ patients, was unchanged in three $(20 \%)$, and worsened in one $(7 \%)$.

Last scheduled visit. Sustained exercise capacity improvement was demonstrated at the last scheduled visit (6MWT: $344 \pm 137 \mathrm{~m}$ ).

\section{Haemodynamical measures}

Results at six weeks. mPAP, CI, PVR, and $\mathrm{S}_{\mathrm{v}, \mathrm{O}_{2}}$ were $6.1 \pm$ $1.3 \mathrm{kPa}(46 \pm 10 \mathrm{mmHg}), 2.65 \pm 0.69 \mathrm{~L} \cdot \mathrm{min}^{-1} \cdot \mathrm{m}^{-2}, 18.7 \pm$ $6.5 \mathrm{U} \cdot \mathrm{m}^{-2}$, and $60 \pm 10 \%$, respectively (all p-values $<0.05$ versus baseline values) (fig. 2).

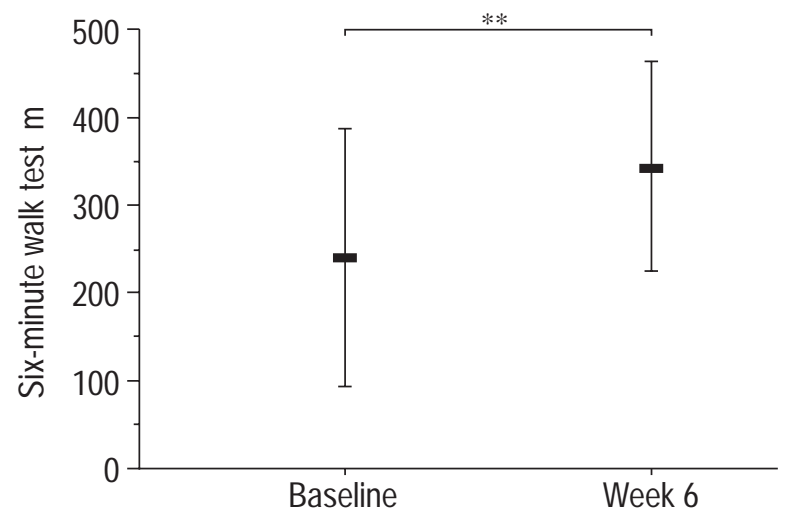

Fig. 1. - Changes in the six-minute walk test from baseline to week 6 after initiation of continuous intravenous epoprostenol. Data are presented as means $\pm \mathrm{SD}$. ${ }^{*}: \mathrm{p}<0.01$.
Last scheduled visit. Sustained haemodynamic improvement was demonstrated at the last scheduled visit: mPAP, $\mathrm{CI}, \mathrm{PVR}$, and $\mathrm{S}_{\mathrm{v}, \mathrm{O}_{2}}$ were $6.1 \pm 1.6 \mathrm{kPa}(46 \pm 12 \mathrm{mmHg})$, $2.43 \pm 0.67 \mathrm{~L} \cdot \mathrm{min}^{-1} \cdot \mathrm{m}^{-2}, 21.4 \pm 10.1 \mathrm{U} \cdot \mathrm{m}^{-2}$, and $58 \pm 10 \%$, respectively.

\section{Survival}

Results at six weeks. During the first six weeks of therapy, two patients $(12 \%)$ died (severe sepsis $(n=1)$, epoprostenol-induced pulmonary oedema $(\mathrm{n}=1))($ table 2$)$ (fig. 3 ).

Follow-up. Patients were monitored for $80 \pm 48$ weeks (range 14-154) after inititiation of epoprostenol. Five patients $(33 \%)$ died of right heart failure $(n=2)$, severe sepsis $(n=2)$ or syncope $(n=1)$ (table 2$)$. Seven of the remaining eight patients had a persistant clinical and haemodynamic improvement.

\section{Transplantation}

Two patients underwent lung transplantation 24 weeks (patient 15) and 52 weeks (patient 6) after initiation of epoprostenol therapy, respectively. Lung pathology showed pulmonary hypertensive arteriopathy similar to that observed in PPH. These patients are now alive and well 46 and 5 months after transplantation.
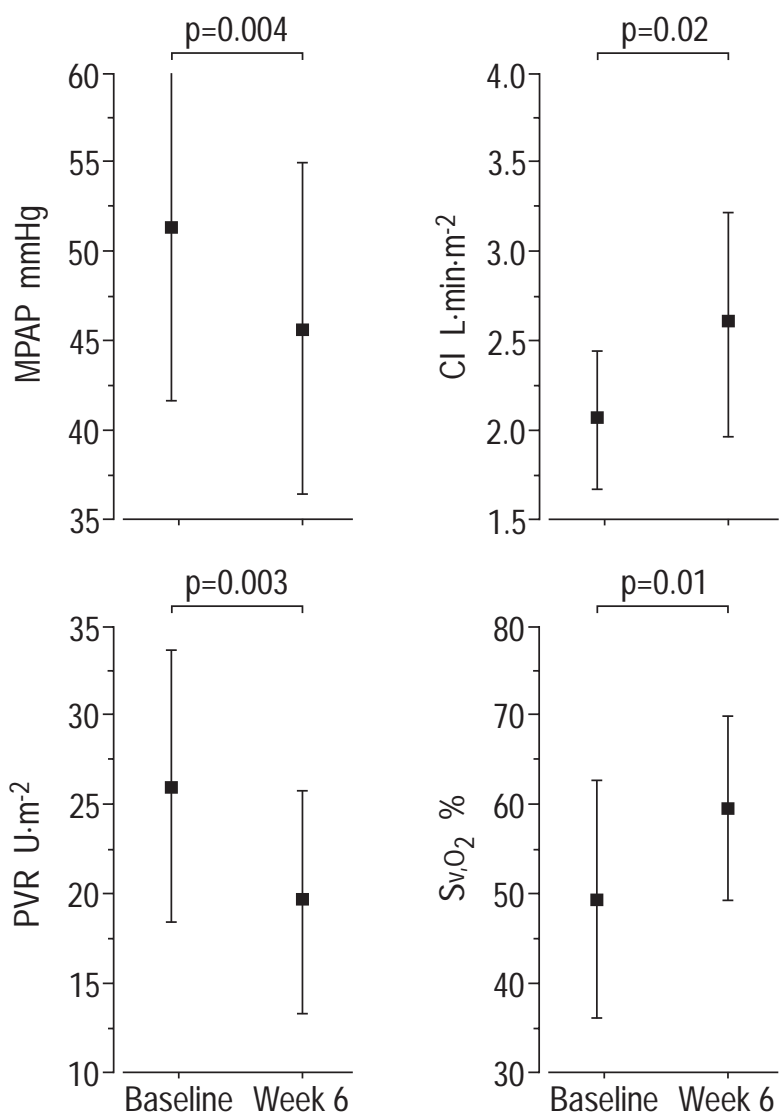

Fig. 2. - Changes in the haemodynamic measures from baseline to week 6 after initiation of continuous intravenous epoprostenol. Data are presented as means $\pm \mathrm{SD}$. mPAP: mean pulmonary artery pressure; $\mathrm{CI}$ : cardiac index; PVR: pulmonary vascular resistance; $\mathrm{S}_{\mathrm{v}, \mathrm{O}_{2}}$ : mean venous oxygen saturation. $(1 \mathrm{mmHg}=0.133 \mathrm{kPa}$.) 
Table 2. - Clinical informations (patients dead at follow-up)

\begin{tabular}{lcccc}
\hline $\begin{array}{l}\text { Patient } \\
\text { No. }\end{array}$ & $\begin{array}{c}\text { Delay } \\
\text { weeks }\end{array}$ & $\begin{array}{c}\text { Last } \\
6 \mathrm{MWT} \\
\mathrm{m}\end{array}$ & $\begin{array}{c}\text { Last } \\
\text { NYHA } \\
\text { functional class* }\end{array}$ & Cause of death \\
\hline 1 & 121 & 520 & II & Severe sepsis (cutaneous) \\
3 & 147 & 380 & III & Right heart failure (syncope) \\
7 & 13 & 380 & II & Syncope (drug-delivery system dysfunction?) \\
10 & 43 & 120 & Right heart failure (syncope) \\
14 & 140 & 310 & II & Severe sepsis (cutaneous); right heart failure (syncope) \\
16 & 3 & 240 & IV & Severe sepsis (cutaneous); right heart failure (syncope) \\
17 & 6 & 185 & Pulmonary oedema \\
\hline
\end{tabular}

6MWT: 6-min walk test. *: the results obtained at the last scheduled visit before the death of the patients are indicated. For patients 16 and 17 , this corresponded to the baseline visit.

\section{Complications}

Minor complications related to the use of epoprostenol were frequent (jaw pain, diarrhoea, flushing, headaches, nausea, and vomiting). Serious complications were linked either to the drug itself (epoprostenol-induced pulmonary oedema, $\mathrm{n}=1$ ) or to the drug-delivery system (including 15 catheter-related sepsis in seven patients, five catheterrelated upper limb deep vein thromboses in three patients, and five catheter-related pneumothorax in five patients). The rate of catheter-related sepsis in the present study population was 0.64 per year and per patient. One unexpected death occurred at home despite dramatic clinical and haemodynamic improvement, suggesting the possibility of a drug-delivery system dysfunction (patient 7 , table 2). Additional problems related to the delivery system included irritation or infection at the catheter site requiring simple outpatient care.

\section{Discussion}

Pulmonary hypertension is a major disabling and lifethreatening complication of CTD [7-14]. In some patients it is associated with mild-to-moderate interstitial disease. In this case the degree of pulmonary hypertension is usually out of proportion with the patients' restrictive pulmonary disease, and it is widely accepted that pulmonary hypertension is not secondary to chronic hypoxaemia or abnormal pulmonary mechanics, but that it is a consequence of an "intrinsic" pulmonary vascular disease [7-14].

Despite rare reports of clinical and haemodynamic improvement with corticosteroids and/or immunosuppressants $[18,19]$, clinicians are usually unable to control or prevent the occurrence of severe pulmonary hypertension. In the present study, all patients presented with NYHA functional class III or IV despite the use of corticosteroids and immunosuppressants, and failed to acutely respond to inhaled nitric oxide, epoprostenol, and oral calcium channel blockers [20]. There is a strong demand for new vasodilator therapy in this population which has an extremely poor prognosis $[7,12]$. Reports of short- and long-term epoprostenol therapy in PPH [1-6] led the authors to propose this drug to patients with CTD. DE LA MATTA et al. [21] have recently reported their experience with iloprost, a prostacyclin analogue, in three patients with pulmonary hypertension secondary to systemic sclerosis. In these patients there was some dis- crepancy between improved NYHA functional class, better quality of life, and the lack of objective haemodynamic amelioration [21]. In the present study, clinical and haemodynamic improvement was demonstrated in most patients six weeks after initiation of epoprostenol. Interestingly, the benefits of epoprostenol in CTD was not restricted to scleroderma, but to all CTD studied, including systemic lupus erythematosus and primary Sjögren's syndrome. Sustained beneficial effects on haemodynamics and exercise capacity in some patients supports the
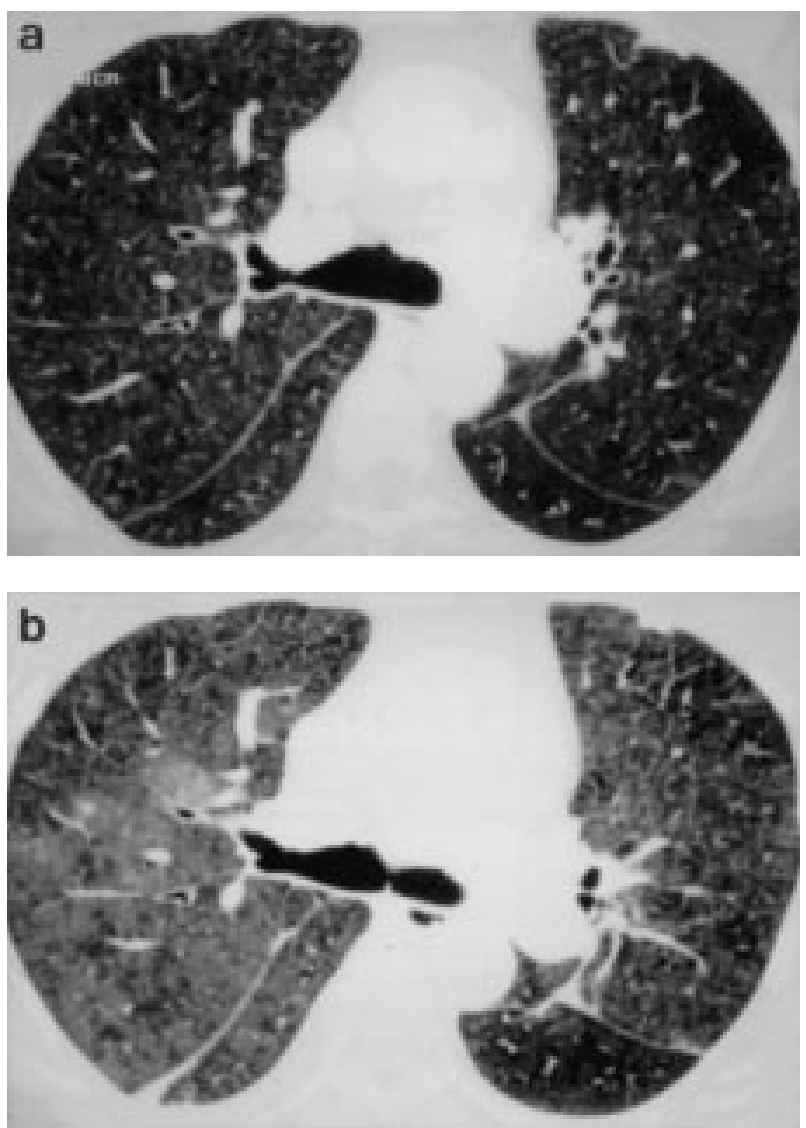

Fig. 3. - Epoprostenol-induced pulmonary oedema in severe pulmonary hypertension secondary to systemic sclerosis (patient 17). a) High-resolution computed tomography of the chest prior to epoprostenol therapy showing mild nodular interstitial opacities. b) High-resolution computed tomography of the chest 3 weeks after initiation of epoprostenol therapy showing worsened interstitial opacities, and right pleural effusion. 
concept that epoprostenol might be used as a primary mode of therapy or as a bridge to transplantation for severe pulmonary hypertension complicating the course of CTD, as already shown in PPH [4-6]. However, it is important to point out that long-term epoprostenol therapy in CTD seemed to be less effective and safe than that reported by McLaughlin et al. [6] in PPH.

There are no consensus guidelines for epoprostenol dose adjustments in PPH. McLaughuin et al. [6] recently published their experience: after baseline evaluation epoprostenol therapy was increased to the maximum tolerated dose over a period of 7 days and subsequently increased by $2 \mathrm{ng} \cdot \mathrm{kg}^{-1} \cdot \mathrm{min}^{-1}$ every month if side-effects permitted or whenever the patient reported an increase in dyspnoea or fatigue that was attributed to $\mathrm{PPH}$. After 16.7 \pm 5.2 months, they reached a dose of $40 \pm 15 \mathrm{ng} \cdot \mathrm{kg}^{-1} \cdot \mathrm{min}^{-1}$ representing a mean increase of $2.4 \mathrm{ng} \cdot \mathrm{kg}^{-1} \cdot \mathrm{min}^{-1}$ every month. Since 1992, the authors' regularly used epoprostenol in PPH with a slower amount of increase in doses. In $81 \mathrm{PPH}$ patients, the authors' have recently reported that the mean doses of epoprostenol at 12 months were $16 \pm 5 \mathrm{ng} \cdot \mathrm{kg}^{-1} \cdot \mathrm{min}^{-1}$, representing a mean increase of $<1$ $\mathrm{ng} \cdot \mathrm{kg}^{-1} \cdot \mathrm{min}^{-1}$ every month. In the present study, from week 2 to week 24, the epoprostenol doses were increased by $1.1 \mathrm{ng} \cdot \mathrm{kg}^{-1} \cdot \mathrm{min}^{-1}$ every month, in general because patients reported an increase in dyspnoea or fatigue attributed to pulmonary hypertension. Such an increase is more important than in the previous large $\mathrm{PPH}$ cohort [22], presumably reflecting a poorer disease control in pulmonary hypertension secondary to CTD.

Patients with a relative degree of immunosuppression due to CTD and its medical management are at risk of infections. Catheter-related sepsis was a major problem in this study leading to unscheduled emergency hospitalizations $(0.64$ catheter-related infections per patient and per year). This rate of septic complications is high but comparable to that observed in PPH in most institutions [6]. There was no relation between the use of steroids and immunosuppressants and the development of sepsis in the present patient population. In addition to catheter-related infections, severe sepsis unrelated to the drug-delivery system were also observed in this study including three cases $(18 \%)$ of fatal cutaneous infections (two patients with severe Raynaud's phenomenon and one patient with digital necrosis complicating the course of systemic lupus erythematosus). This rate of fatal infections is uncommon in PPH [6]. In addition, the risk of catheter-related thrombosis is high in this population, especially in patients with antiphospholipid antibody. Four out of 17 patients $(24 \%)$ were anticardiolipid-positive with no history of thromboembolic disease. These patients received oral anticoagulants in doses adjusted to achieve an INR of 2.0. Two patients developed sepsis-related thrombosis after initiation of epoprostenol and were subsequently advised to increase their doses to achieve an INR between 3.0 and 3.5 , as previously recommended [23]. This high complication rate underscores the need for an improved delivery system of epoprostenol or its analogues (i.e. subcutaneous, aerosolized or oral) [24, 25].

Severe pulmonary oedema rapidly complicating continuous intravenous epoprostenol was observed in a patient with systemic sclerosis. It is known that epoprostenol can promote pulmonary oedema in pulmonary veno-occlusive disease or pulmonary capillary haemangiomatosis presumably because of increased pulmonary perfusion in the presence of downstream vascular obstruction $[2,26]$. Interestingly, significant venous involvement has been demonstrated in some patients with pulmonary hypertension secondary to systemic sclerosis $[27,28]$ and might therefore explain the occurrence of pulmonary oedema in the present patient who unfortunately could not undergo necropsy. In the light of this recent experience it is now recommended to systematically perform high-resolution computed tomography of the chest before initiating vasodilator therapy in patients with pulmonary hypertension and to repeat this procedure in case of subsequent clinical deterioration with epoprostenol. Lung biopsy should be discussed in cases of significant abnormalities in order to avoid clinical deterioration with vasodilator therapy.

Intravenous infusion of iloprost has been showed to improve Raynaud's phenomenon in some patients with systemic sclerosis [29]. In the present series, 13 (76\%) patients displayed severe Raynaud's phenomenon at baseline. Two $(15 \%)$ patients subjectively described an improvement with epoprostenol and $11(85 \%)$ reported it was stable. No objective measurement of digital blood flow was analysed.

In conclusion, this open monocentre uncontrolled study indicates that short-term continuous intravenous epoprostenol plus conventional therapy is effective in a majority of patients with connective tissue diseases, as demonstrated by the better New York Heart Association functional class, exercise tolerance, and haemodynamics at six weeks. However, this study reports several cases of major complications including severe sepsis and pulmonary oedema, and long-term results are still uncertain. Additional information is needed to evaluate the benefit: risk ratio of longterm epoprostenol therapy in pulmonary hypertension secondary to connective tissue diseases.

Acknowledgements. The authors wish to dedicate this work to F. Brenot ${ }^{\dagger}$ (1955-1996).

\section{References}

1. Rubin LJ, Groves BM, Reeves JT, Frosolono M, Handel F, Cato AE. Prostacyclin-induced acute pulmonary vasodilatation in primary pulmonary hypertension. Circulation 1982; 66: 334-338.

2. Rubin LJ, Mendoza J, Hood M, et al. Treatment of primary pulmonary hypertension with continuous intravenous prostacyclin (epoprostenol): results of a randomized trial. Ann Intern Med 1990; 112: 485-491.

3. Higenbottam TW, Wheeldon D, Wells F, Wallwork J. Long-term treatment of primary pulmonary hypertension with continuous intravenous epoprostenol (prostacyclin). Lancet 1984; i: 1046-1047.

4. Barst RJ, Rubin LJ, McGoon MD, Caldwell EG, Long WA, Levy PS. Survival in primary pulmonary hypertension with long-term continuous intravenous prostacyclin. Ann Intern Med 1994; 121: 409-415.

5. Barst RJ, Rubin LJ, Long WA, et al. A comparison of continuous intravenous epoprostenol (prostacyclin) with conventional therapy for primary pulmonary hypertension. $N$ Engl J Med 1996; 334: 296-301.

6. McLaughlin VV, Genthner DE, Panella RN, Rich S. Reduction in pulmonary vascular resistance with long-term epoprostenol (prostacyclin) therapy in primary pulmonary hypertension. $N$ Engl J Med 1998; 338: 273-277. 
7. Brundage BH. Pulmonary hypertension in collagen vascular disease. In: Fishman A, ed. The Pulmonary Circulation. Philadelphia University of Pennsylvania Press, 1990: pp. 353-358.

8. Brenot F, Simonneau G. Risk factors for primary pulmonary hypertension. In: Rubin L, Rich S, eds. Primary Pulmonary Hypertension. New York, Marcel Dekker, 1997: pp. 131-149.

9. Salerni R, Rodnan GP, Leon DF, Shaver JA. Pulmonary hypertension in the CREST syndrome variant of progressive systemic sclerosis (scleroderma). Ann Intern Med 1977; 86: 394-399.

10. Ungerer RG, Tashkin DP, Furst D, et al. Prevalence and clinical correlates of pulmonary arterial hypertension in progressive systemic sclerosis. Am JMed 1983; 75: 65-74.

11. Stupi AM, Steen VD, Owens GR, EL Barnes, Medsger TA Jr. Pulmonary hypertension in the CREST syndrome variant of systemic sclerosis. Arthritis Rheum 1986; 29: 515-524.

12. Koh ET, Gladman DD, Abu-Shakra M. Pulmonary hypertension in systemic sclerosis: an analysis of 17 patients. Br J Rheumatol 1996; 35: 989-993.

13. Asherson RA, Higenbottam TW, Dihn-Xuan AT, Khamashta MA, Hughes GR. Pulmonary hypertension in a lupus clinic: experience with twenty four patients. $J$ Rheumatol 1990; 17: 1292-1298.

14. Sato T, Matsubara O, Tanaka Y, Kasuga T. Association of Sjögren's syndrome with pulmonary hypertension: report of two cases and review of the literature. Hum Pathol 1993; 24: 199-205.

15. Rich S, Dantzer DR, Ayres SM, et al. Primary pulmonary hypertension: a national prospective study. Ann Intern Med 1987; 107: 216-223.

16. Rubin LJ. Primary pulmonary hypertension. $N$ Engl $J$ Med 1997; 335: 111-117.

17. Sitbon O, Brenot F, Denjean A, et al. Inhaled nitric oxide as a screening vasodilator agent in primary pulmonary hypertension: a dose-response study and comparison with prostacyclin. Am J Respir Crit Care Med 1995; 151: 384-389.

18. Dahl M, Chalmers A, Wade J, Calverley D, Munt B. Ten year survival of a patient with advanced pulmonary hypertension and mixed connective tissue disease treated with immunosuppressive therapy. $J$ Rheumatol 1992; 19: 1807-1809.

19. Karmochkine M, Wechsler B, Godeau P, Brenot F, Jagot J-L, Simonneau G. Improvement of severe pulmonary hypertension in a patient with SLE. Ann Rheumatol Dis 1996; 55: 561-562.

20. Sitbon O, Humbert M, Jagot J-L, et al. Inhaled nitric oxide as a screening agent to safely identify responders to oral calcium-channel blockers in primary pulmonary hypertension. Eur Respir J 1998; 12: 265-270.

21. De la Mata J, Gomez-Sanchez MA, Aranzana M, GomezReino JJ. Long-term iloprost infusion therapy for severe pulmonary hypertension in patients with connective tissue diseases. Arthritis Rheum 1994; 37: 1528-1533.

22. Sitbon $\mathrm{O}$, Gentil B, Humbert $\mathrm{M}$, et al. Long-term epoprostenol (prostacyclin) therapy in primary pulmonary hypertension: results from a large French monocenter study. Eur Respir J 1998; 12: Suppl. 28, 237s.

23. Khamashta MA, Cyadrado MJ, Mujic F, Taub NA, Hunt BJ, Hughes GRV. The management of thrombosis in the antiphospholipid-antibody syndrome. N Engl J Med 1995; 332: 993-997.

24. Olschewski H, Walmrath D, Schermuly R, Ghofrani A, Grimminger F, Seeger W. Aerosolized prostacyclin and iloprost in severe pulmonary hypertension. Ann Intern Med 1996; 124: 820-824.

25. Okano Y, Yoshioka T, Shimouchi A, Satoh T, Kunieda T. Orally active prostacyclin analogue in primary pulmonary hypertension. Lancet 1997; 349: 1365.

26. Humbert M, Maître S, Capron F, Rain B, Musset D, Simonneau G. Pulmonary edema complicating continuous intravenous prostacyclin in pulmonary capillary hemangiomatosis. Am J Respir Crit Care Med 1998; 157: 1681-1685.

27. Naeye RL. Pulmonary vascular lesions in systemic scleroderma. Dis Chest 1963; 44: 374-380.

28. Yousem SA. The pulmonary pathologic manifestations of the CREST syndrome. Hum Pathol 1990; 21: 467-474.

29. Rademaker M, Cooke ED, et al. Comparison of intravenous infusions of iloprost and oral nifedipine in treatment of Raynaud's phenomenon in patients with systemic sclerosis: a double blind randomised study. BMJ 1989; 298: 561-564. 